\title{
Climatic Drivers of Greening Trends in the Alps
}

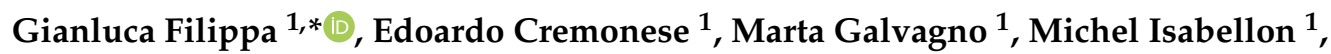 \\ Arthur Bayle ${ }^{2}$, Philippe Choler ${ }^{2}$, , Bradley Z. Carlson ${ }^{3}$, Simone Gabellani ${ }^{4}$, \\ Umberto Morra di Cella ${ }^{1,4}$ (i) and Mirco Migliavacca ${ }^{5}$
}

1 Environmental Protection Agency of Aosta Valley-Climate Change Unit, Loc. La Maladière, 48-11020 Saint-Christophe (AO), Italy; e.cremonese@arpa.vda.it (E.C.); m.galvagno@arpa.vda.it (M.G.); m.isabellon@arpa.vda.it (M.I.); u.morradicella@arpa.vda.it (U.M.d.C.)

2 Univ. Grenoble Alpes, Univ. Savoie Mont Blanc, CNRS, LECA, F-38000 Grenoble, France; arthur.bayle@univ-grenoble-alpes.fr (A.B.); philippe.choler@univ-grenoble-alpes.fr (P.C.)

3 Centre de Recherches sur les Ecosystèmes d'Altitude (CREA), Observatoire du Mont-Blanc, F-74400 Chamonix, France; bcarlson@creamontblanc.org

4 CIMA Research Foundation-Via A. Magliotto, 2, I-17100 Savona, Italy; simone.gabellani@cimafoundation.org

5 Max Planck Institute for Biogeochemistry Department Biogeochemical Integration Hans-Knöll-Str. 10, D-07745 Jena, Germany; mmiglia@bgc-jena.mpg.de

* Correspondence: g.filippa@arpa.vda.it

Received: 2 October 2019; Accepted: 25 October 2019; Published: 29 October 2019

\begin{abstract}
Since the 1980s, vegetated lands have experienced widespread greening at the global scale. Numerous studies have focused on spatial patterns and mechanisms of this phenomenon, especially in the Arctic and sub-Arctic regions. Greening trends in the European Alps have received less attention, although this region has experienced strong climate and land-use changes during recent decades. We studied the rates and spatial patterns of greening in an inner-alpine region of the Western Alps. We used MODIS-derived normalized difference vegetation index (NDVI) at 8-day temporal and $250 \mathrm{~m}$ spatial resolution, for the period 2000-2018, and removed areas with disturbances in order to consider the trends of undisturbed vegetation. The objectives of this study were to (i) quantify trends of greening in a representative area of the Western Alps; and (ii) examine mechanisms and causes of spatial patterns of greening across different plant types. We show that $63 \%$ of vegetated areas experienced significant trends during the 2000-2018 period, of which only $8 \%$ were negative. We identify (i) a climatic control on spring and autumn phenology with contrasting effects depending on plant type and elevation, and (ii) land-use change dynamics, such as shrub encroachment on abandoned pastures and colonization of new surfaces at high elevation. Below $1500 \mathrm{~m}$, warming temperatures promote incremental greening in the transition from spring to summer, but not in fall, suggesting either photoperiod or water limitation. In the alpine and sub-alpine belts ( $>1800 \mathrm{~m}$ asl), snow prevents vegetation development until late spring, despite favorable temperatures. Instead, at high elevation greening acts both in summer and autumn. However, photoperiod limitation likely prevents forested ecosystems from fully exploiting warmer autumn conditions. We furthermore illustrate two emblematic cases of prominent greening: recent colonization of previously glaciated/non vegetated areas, as well as shrub/tree encroachment due to the abandonment of agricultural practices. Our results demonstrate the interplay of climate and land-use change in controlling greening dynamics in the Western Alps.
\end{abstract}

Keywords: MODIS; BFAST; Alps; NDVI; snow water equivalent; warming; land-use change 


\section{Introduction}

Since the 1980s, vegetated lands have experienced widespread greening at a global level [1]. Growing season integrated leaf area index has increased significantly across $25-50 \%$ of the vegetated areas [2], and the normalized difference vegetation index (NDVI) has increased globally at a rate of $0.0013 \mathrm{yr}^{-1}$ for the 1982-2011 period [1]. Accurate descriptions of greening dynamics and controls are crucial because increased greening is associated with increased carbon uptake by vegetation [3], with important implications on the carbon dioxide balance [4]. A large body of literature shows that Arctic and sub-Arctic environments are greening faster than temperate areas in response to accelerated warming in these regions [5-8]. However, substantially less work has been devoted to quantifying and understanding patterns of greening in temperate mountain regions, such as the European Alps. Yet, the Alps represent a key area where climate and land-use changes are already strongly influencing ecosystem processes, and shifts in vegetation structure have immediate consequences for services provided to densely populated alpine valleys. Temperature increase is about double than the global average [9,10], and snow cover duration has decreased above $2000 \mathrm{~m}$ in the last 50 years [11], although climatic trends since the 1990s are weaker [12]. New surfaces are becoming available for primary succession, including recently deglaciated areas [13], and an upward shift of alpine vegetation has been observed, documenting the colonization of previously non-vegetated areas and increasing species richness on mountain summits [14]. Other surfaces are radically changing because of a combination of land-use and climatic change, resulting, for example, in tree-line rise [15,16], shift in species [14,17], and pasture abandonment. A recent study [18] documented widespread greening in grassland, low-shrub, and scree slopes of a protected area in the French Alps and proposed rising temperatures and decreased snow-cover duration as the main drivers. However, the positive effect of rising temperatures can be modulated by other factors (e.g., drought, photoperiod) in a complex inter-play. For example, water deficit may offset the benefit derived from warmer temperatures in mountain grasslands [19]. Forested ecosystems could also be subjected to greening trends via biomass increase, forest densification, and shifts in species composition. An alpine-scale study on land surface phenology showed extensive lengthening of the growing season and demonstrated the role of snow duration on phenology trends in the last 20 years [20].

Changes in vegetation structure can be attributed to two categories: (1) gradual changes that may determine increase or decrease of plant productivity, generally referred to as greening or browning [21], and (2) abrupt changes due to disturbances, such as fire, windstorms, avalanches, or land reshaping. Indeed, de Jong et al. [21] demonstrate the importance of accounting for abrupt and gradual changes when analyzing long-term NDVI time series. To the best of our knowledge, abrupt changes have not been taken into account while studying greening trends in the Alps. Furthermore, Emmett et al. [22] showed the importance of disentangling climate and disturbance effects when studying greening trends. One of the most prominent tools for the analysis of trends and abrupt changes in time series of vegetation indices is the Breaks For Additive Seasonal and Trend (BFAST) method [23,24], which was successfully used in global and regional analyses. In particular, a recent study [25] deployed the BFAST method on MODIS-derived NDVI time series in a mountain environment and confirmed the robustness of this approach also in complex terrain.

In this study, we used 19 years of MODIS-derived NDVI to answer the following questions:

(1) What is the magnitude of greening trends in the Western Alps when the role of the disturbance is accounted for?

(2) What are the mechanisms and causes of the spatial patterns of greening across plant types, elevation gradients, and seasons?

We hypothesize that (1) greening trends at high elevation documented for other Alpine regions may be due to warmer temperatures and longer snow-free periods; and (2) warmer summer temperatures in the valley lowlands can also lead to greening, and the BFAST method can help to identify it. 


\section{Materials and Methods}

\subsection{Study Area, Climate Data, and Vegetation Mapping}

This study was conducted in Aosta Valley, an inner-alpine valley located in north western Italy. The large elevation range between 300 and $4800 \mathrm{~m}$ (mean: $2100 \mathrm{~m}$ ), over a relatively small surface $\left(3262 \mathrm{~km}^{2}\right)$, produces steep temperature gradients, with mean annual temperatures of $14{ }^{\circ} \mathrm{C}$ at $500 \mathrm{~m}$ down to $-3{ }^{\circ} \mathrm{C}$ at $3000 \mathrm{~m}$ for the period 2000-2018. The continental character of the valley results in pronounced precipitation gradients, with cumulative values of more than $1800 \mathrm{~mm}^{-1} \mathrm{re}^{-1}$ in peripheral areas (west and south-east boundaries), and local minima of $500 \mathrm{~mm} \mathrm{year}^{-1}$ in the center of the region.

Daily gridded temperature, precipitation, and evapotranspiration data at $100 \mathrm{~m}$ spatial resolution were used as climatic descriptors for the period 2000-2018. Precipitation and temperature are derived from geostatistical interpolation of ground data from the regional network of automatic weather stations [26]. Daily temperature (precipitation, evapotranspiration) maps were averaged (cumulated) to a long-term annual product, as well as seasonally, considering meteorological seasons. A simplified water balance was estimated as the difference between precipitation and evapotranspiration. Evapotranspiration was computed using the hydrological model Continuum [26,27]. The model is distributed and solves the conservation equation for mass and energy at the soil on a regular grid with $100 \mathrm{~m}$ resolution. It estimates latent and sensible heat fluxes using a bulk transfer approach based on bulk transfer formula [28]. It is used operationally in the region for flood forecasting and water managements. Maps of snow water equivalent (SWE, $500 \mathrm{~m}$ spatial, 15 days temporal resolution) were obtained from a statistical model combining MODIS snow covered area, snow depth data from a ground meteorological network, manual SWE measurements, and topographical attributes in a multiple-regression-krieging framework. These data were used to describe the snow climatology of the study area, by means of two average maps: mean maximum SWE and mean snow melt date for the period 2002-2018.

Vegetation types were mapped by photo-interpretation of aerial photographs collected in the years 2005 and 2006. Vegetation mapping was performed according to the habitats defined in Annex I of the Habitats Directive [29] and described in detail in [30]. The final product, digitized in the form of polygons at a scale ranging between 1:5000 and 1:10,000, was then rasterized at $250 \mathrm{~m}$ to match the spatial resolution of the satellite products. The 56 habitats identified were further aggregated in 8 plant functional types (PFT, Figure 1). Forests cover $34 \%$ of the study area, with a $20 \%$ contribution of deciduous species and $14 \%$ of evergreen needleleaf forest. The most abundant species is larch (the only deciduous needleleaf species, DNF), which alone covers $14 \%$ of the whole surface. Grasslands cover $26 \%$ of the surface, with only $4 \%$ meadows and $21 \%$ pastures. The second most abundant type is vegetated scree slopes, with $29 \%$ cover. Finally, $5 \%$ of the surface is covered by glaciers and recently deglaciated areas. 

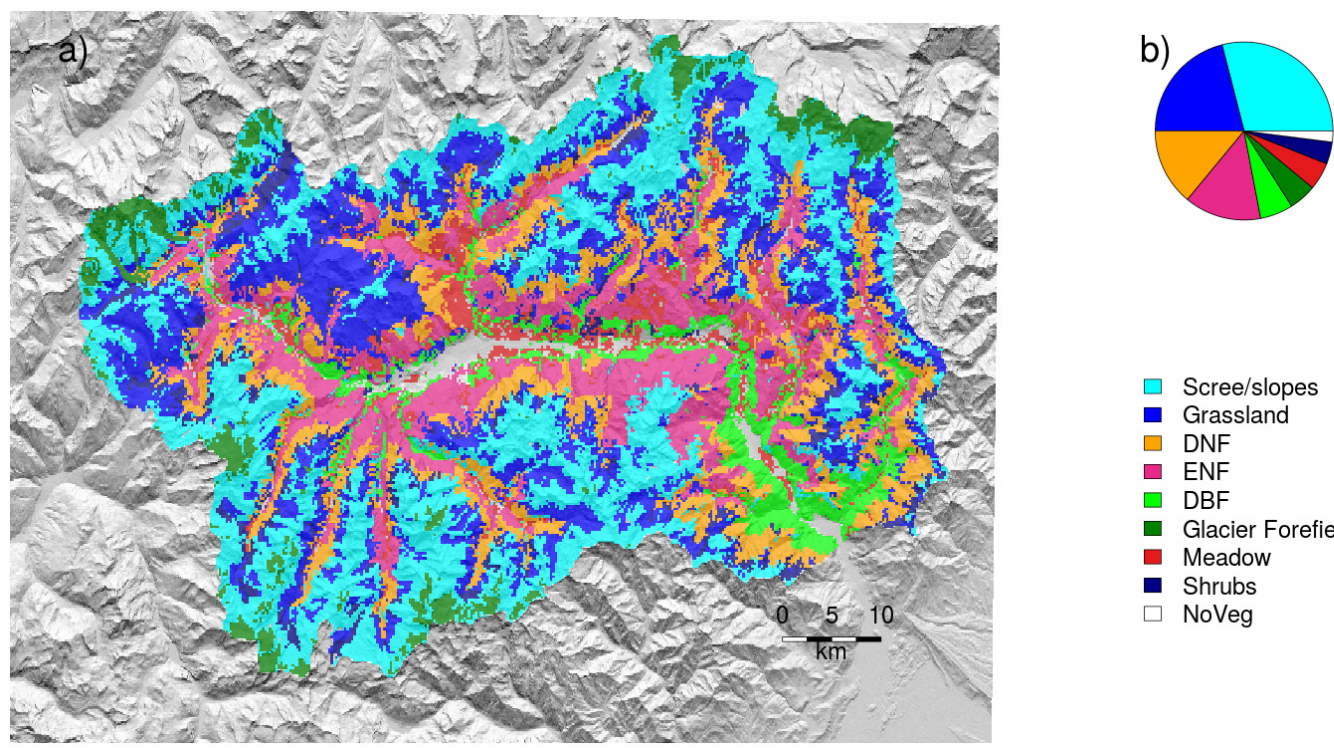

Figure 1. Map of the vegetation macro-types included in this study (a), along with \% cover for each type (b). DNF: deciduous needleleaf forest; ENF: evergreen needle-leave forest; DBF: deciduous broadleaf forest.

\subsection{Satellite Data}

All satellite data cover the period from February 2000 to December 2018. MODIS Terra surface reflectance images (MOD09Q1) collection 6 at 250 spatial and 8 days temporal resolution [31] were downloaded from National Aeronautics and Space Administration (NASA) ftps using the MODIStsp $\mathrm{R}$ package [32]. The same was used to compute NDVI maps, which were then masked according to the MOD09Q1 quality flags; only pixels classified as of "best quality" were retained. NDVI was preferred over the enhanced vegetation index (EVI) for consistency with the majority of studies on global greening trends, which considered NDVI only. The MOD10A2 collection 6 snow covered area (SCA) standard product was also downloaded and re-sampled at $250 \mathrm{~m}$ spatial resolution using the nearest neighbor interpolation method. The SCA dataset was used to compute a winter baseline for NDVI with a method similar to [33]. First, the resampled SCA dataset was used to mask snow-free pixels. For each pixel, the 5th percentile of NDVI was computed on the whole time series to determine a per-pixel climatological minimum snow-free NDVI. This minimum snow-free map was used to mask each 8-day NDVI map, with values lower than the climatological minumum substituted with it on a pixel basis.

Corrected 8-day maps were averaged to a monthly product which was used in all subsequent analyses.

\subsection{Data Analysis}

The BFAST (Breaks For Additive Seasonal and Trend) method implemented in the bfast $R$

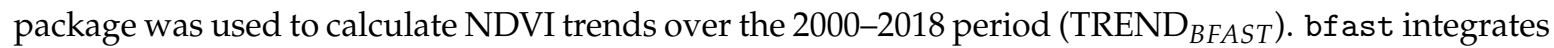
the decomposition of time series into trend, seasonal, and remainder components with methods for detecting and characterizing abrupt changes within the trend and seasonal components [23,24]. As such, this method is particularly suitable for the detection of disturbed time series and concomitant trend detection. Pixels showing clear breaks in either long-term trend or seasonal components were removed from the analysis of trends.

Because the wide range in mean NDVI across different PFTs can complicate the interpretation of absolute NDVI trends, TREND $B F A S T$ values were also expressed as percentage of the long term pixel-based mean and further multiplied by 20 to represent the cumulated NDVI increase in the $\sim$ two MODIS decades 2000-2018 (see Figure 2b). We also calculated another metric derived from NDVI, 
the area under the the curve (AUC, i.e., the NDVI integral), used as a surrogate for aboveground productivity [34]. AUC was computed after subtracting the minimum baseline to the seasonal values. In addition to the BFAST method, we computed NDVI trends with the approach proposed by [18]. We extracted maximum summer NDVI for each year and grid cell and calculated the trend by the Theil-Sen median slope method and Mann-Kendall method for significance (TREND $M A X,[35]$ ). Pixel-based trends for temperature and precipitation data were computed by decomposing the time series according to [36]. The slope of the trend component was then estimated with the Theil-Sen median slope method [35]. Precipitation trend was rarely significant and discarded from subsequent analysis.

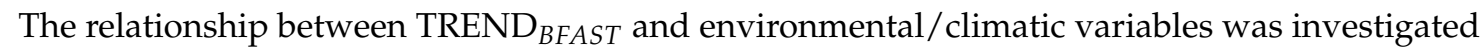
with Random Forests (RF) using the ranger package [37]. Explanatory variables included in the model are summarized in Table 1. Several important climatic variables were excluded because of high autocorrelation, identified by inspecting variable importance table: these include average temperatures (e.g., annual T, spring $\mathrm{T}$ both correlated to summer $\mathrm{T}$ ) and phenological variables (growing season length, snow melt date, both correlated to summer T and maximum SWE). All models were run with the caret package [38] in R [39]. Model performance metrics are calculated from 20-fold cross-validation. As for RF parameters, we let vary the number of variables to possibly split at in each node (mtry) and the splitting rule (variance vs. extratrees, see [40]), whereas minimal node size and tree number were kept as default (5 and 500, respectively).

The dynamics of colonization of new surfaces was showcased by extracting NDVI time series in the proglacial area of the Rutor Glacier $\left(45^{\circ} 40^{\prime} 12^{\prime \prime} \mathrm{N}, 6^{\circ} 59^{\prime} 11^{\prime \prime} \mathrm{E}, 2560 \mathrm{~m}\right.$ a.s.1.). We focused on three points corresponding to markedly different ages of deglaciation, which was defined by visual inspection of historical aerial photographs retrieved from the web map service (WMS) of the Geoportale Nazionale (http:/ / www.pcn.minambiente.it/mattm/en/view-service-wms/).

Table 1. Environmental and climatic variables used in the random forest (RF) model.

\begin{tabular}{|c|c|c|}
\hline Variable Type & Details & Acronyms \\
\hline $\begin{array}{l}\text { Thermal } \\
\text { conditions }\end{array}$ & $\begin{array}{l}\text { Mean summer temperature, temperature trend, heat load } \\
\text { index [41] }\end{array}$ & Tsummer, Ttrend, hli \\
\hline Water status & $\begin{array}{c}\text { Summer water balance, maximum snow water equivalent, } \\
\text { annual and summer precipitation }\end{array}$ & $\begin{array}{l}\text { PmET, maxSwe (snow water } \\
\text { equivalent), P, Psummer }\end{array}$ \\
\hline Vegetation type & $\begin{array}{c}\text { plant macrotype as in Figure } 1 \text { and mean max normalized } \\
\text { difference vegetation index (NDVI) }\end{array}$ & pft, maxNDVI \\
\hline
\end{tabular}

All analyses were conducted with the R software for statistical computing, version 3.6.1 [39].

\section{Results}

\subsection{Comparison of TREND $D_{B F A S T}$ and TREND $M A X$}

The BFAST method applied to the 2000-2018 NDVI imagery on Aosta Valley revealed that 31\% of pixels showed a disturbed time series characterized by one or more break points (Table 2). Disturbed pixels were mainly located at low elevation $(69 \%$ below $1500 \mathrm{~m})$. Deciduous forests showed the highest percentage of disturbed pixels, but evergreens and meadows followed closely. Because an analysis of the break points was beyond the scope of this paper, disturbed pixels were masked out before computing the final trend map (Figure 2). A small fraction (6\%) of the non-disturbed pixels showed no trends, while the remaining (63\%) were characterized by a significant NDVI trend. Among these, only $8 \%$ showed negative trends, whereas $92 \%$ of trends were found to be positive. TREND $B F A S T$ ranged between $-0.001 \mathrm{yr}^{-1}$ and $0.004 \mathrm{yr}^{-1}$ and was slightly positively skewed (mean $=0.0011$, median 0.00094). Different plant functional types were characterized by distinct absolute trend values; deciduous broadleaf forests (DBF) and meadows had the highest rates of greening, followed by evergreen and larch forests (DNF). Relative trends (expressed as percentage of the mean NDVI and integrated over the length of the time series, Figure $2 c, d$ ) ranged between $\sim-9$ and $55 \%$. The highest 
median values above 30\% were found for Glacier Forefield category. Scree slopes vegetation also showed a median increase of greening higher than $15 \%$. For the other plant types, relative TREND BFAST were rather homogeneous.
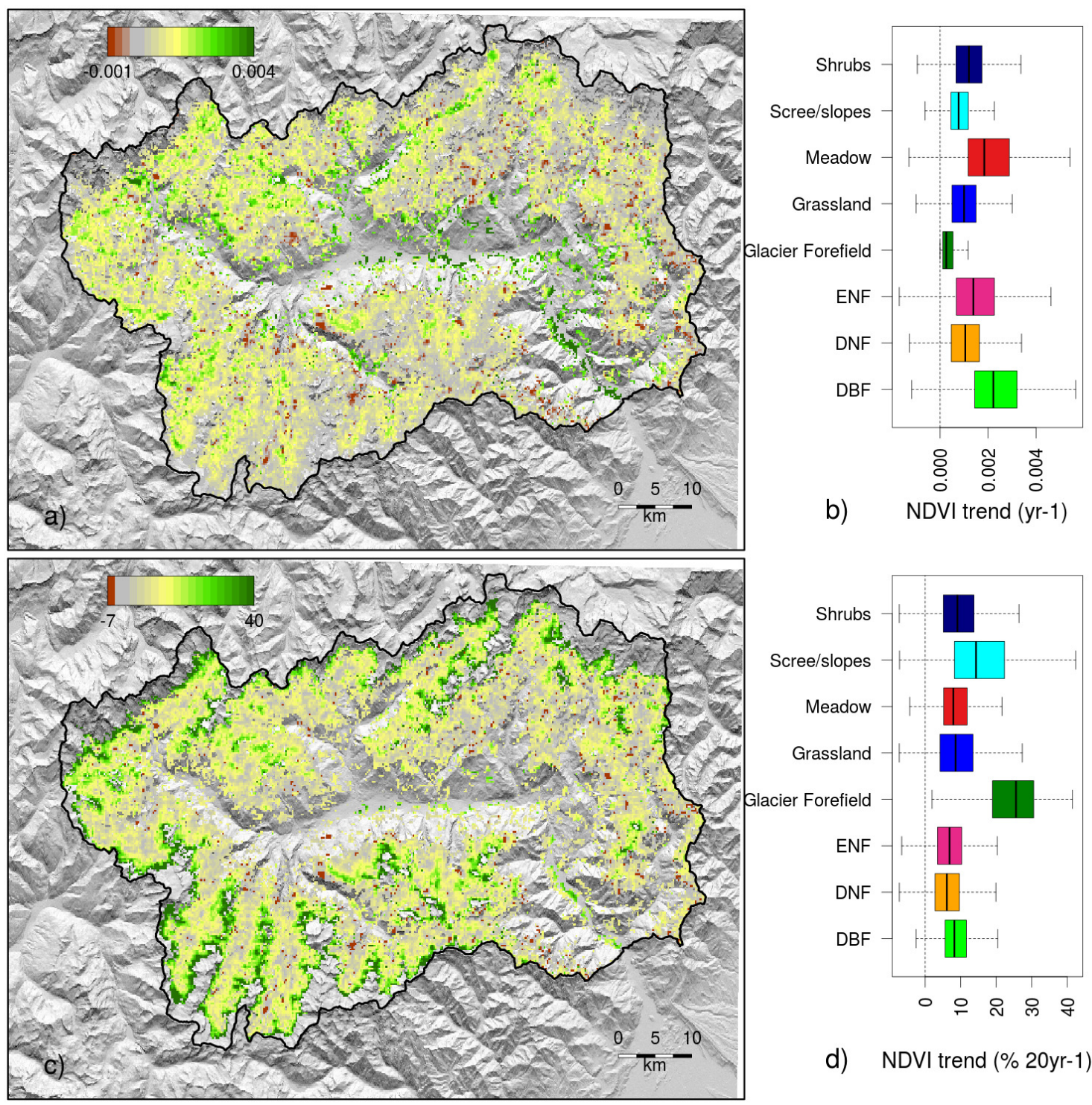

d) NDVI trend (\% 20yr-1)

Figure 2. (a-c) Maps of TREND $B F A S T$. Absolute trend values are shown in map (a), whereas map in (c) shows total (2000-2018) NDVI increase expressed in \% relative to the long term pixel-based mean. (b-d) Boxplots of significant trends separated by plant macro-types (colors of boxplots are consistent with plant functional types (PFTs) of Figure 1). Note that outliers (i.e., data points falling outside 1.5 times the interquartile range) are not drawn for clarity. Absolute trends are plotted in (b), whereas relative $(\%)$ trends are plotted in (d).

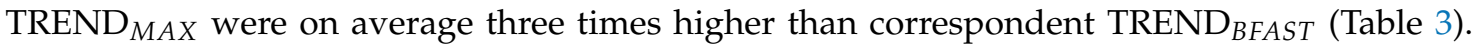
However, the number of pixels with significant TREND $\mathrm{TAX}_{\mathrm{X}}$ were only $16 \%$, much lower than for TREND $_{B F A S T}(63 \%)$. In addition, we found a complex relationship between trends retrieved with the two methods (Figure 3). The expected linear relationship between the two trends holds as long as maximum summer NDVI remains below 0.6. At higher summer NDVI values, only the BFAST method was able to further detect increasing trends, and the relationship between the two trends reversed. Correspondingly, the number of significant pixels detected by the TREND ${ }_{M A X}$ method decreased. 
This behavior suggests that the TREND ${ }_{M A X}$ method is more prone to NDVI saturation compared to TREND $_{B F A S T}$ method.

Table 2. Proportion (\%) of pixels showing a significant trend or disturbed time series based on the Breaks For Additive Seasonal and Trend (BFAST) method, separated according to plant macro-types and two elevation bands. The proportion is calculated by dividing the number of disturbed pixels by the total number of pixels of a given plant type, except for the totals in parentheses (bottom row), which refer to the number of pixels in the elevation band.

\begin{tabular}{ccccc}
\hline Plant Macro-Type & $\begin{array}{c}\text { \% Pixels with } \\
\text { Significant Trend }\end{array}$ & $\begin{array}{c}\text { \% Disturbed Pixels } \\
\text { below 1500 } \mathbf{~}\end{array}$ & $\begin{array}{c}\text { \% Disturbed Pixels } \\
\text { above 1500 m }\end{array}$ & $\begin{array}{c}\text { Total Disturbed } \\
\text { Pixels }\end{array}$ \\
\hline Deciduous broadleaf & 22 & 75 & 2 & 77 \\
forest & 35 & 53 & 11 & 65 \\
Meadow & 30 & 37 & 32 & 69 \\
$\begin{array}{c}\text { Evergreen } \\
\text { Deciduous needleleaf }\end{array}$ & 61 & 9 & 28 & 37 \\
forest & 85 & 5 & 10 & 15 \\
Shrubs & 87 & 2 & 10 & 12 \\
Grassland & 76 & 1 & 22 & 23 \\
Scree/slopes & 33 & n.a. & 56 & 56 \\
Glacier Forefield & $\mathbf{6 3}$ & $\mathbf{1 4}(\mathbf{6 9 )}$ & $\mathbf{1 7}(\mathbf{2 1})$ & 31 \\
Total & & & & \\
\hline
\end{tabular}

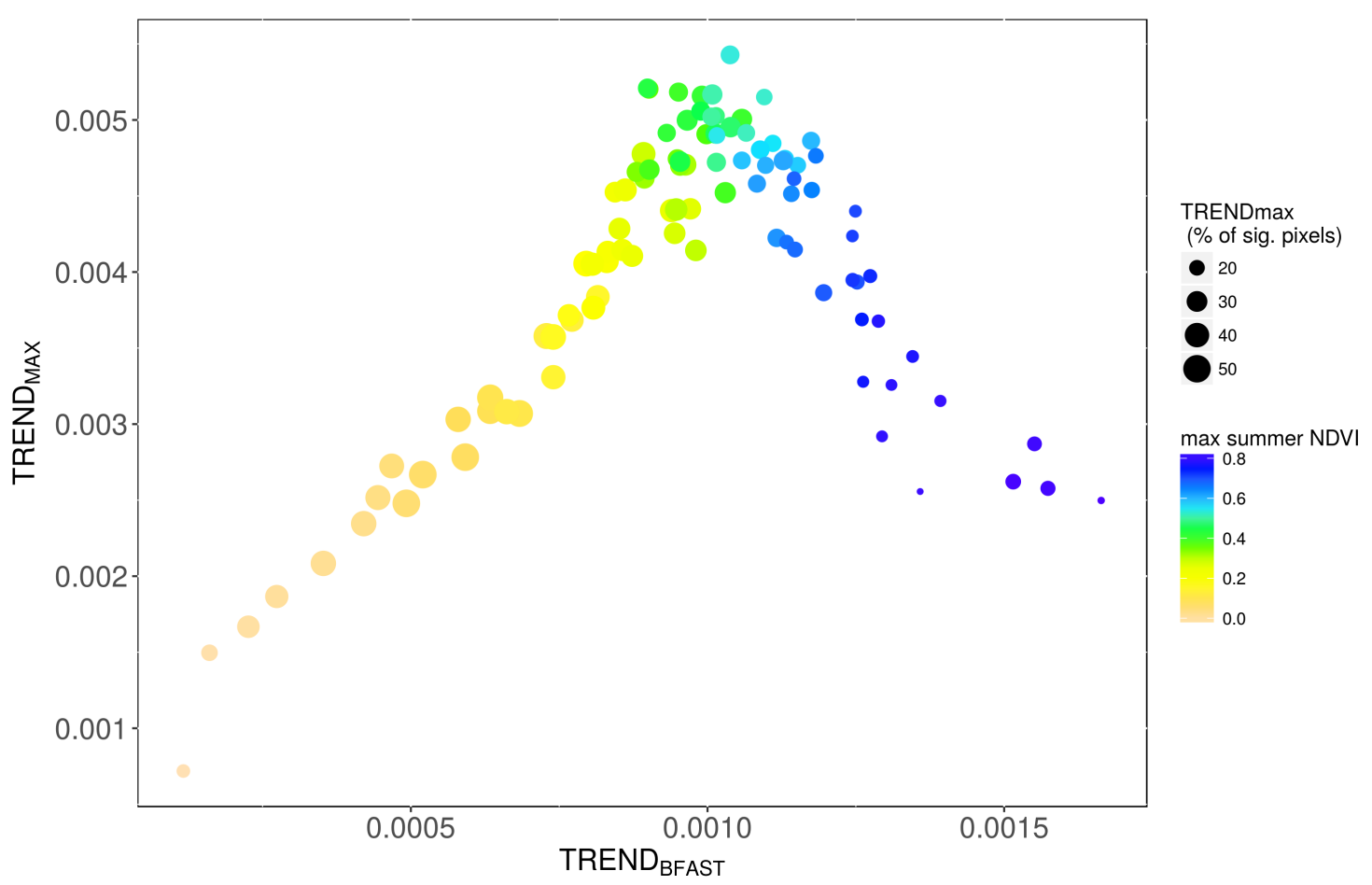

Figure 3. The relationship between TREND ${ }_{B F A S T}$ and TREND $_{M A X}$. Grid cell values from both maps are binned according to long term average maximum summer NDVI (bins 0.01 ). Color is mapped to the long term maximum summer NDVI, whereas point size is proportional to the number of pixels showing a significant TREND $M A X$. 
Table 3. Statistics of the NDVI trends computed by the two different approaches: (1) using the BFAST method (TREND $\left.{ }_{B F A S T}\right)$ and (2) with the Sen's slope method on yearly maximum NDVI (TREND MAX $_{\text {). }}$ Trends are multiplied by a factor of $10^{3}$.

\begin{tabular}{ccc}
\hline Statistics & TREND $_{\text {MAX }}$ & TREND $_{\text {BFAST }}$ \\
\hline 10th quantile & 1.88 & 0.09 \\
25th quantile & 2.78 & 0.46 \\
Median & 3.90 & 0.94 \\
75th quantile & 5.26 & 1.51 \\
90th quantile & 6.66 & 2.17 \\
Sig. pixels (\%) & 16 & 63 \\
\hline
\end{tabular}

\subsection{Factors Controlling NDVI Trends}

The RF model showed good performance in describing NDVI trends (TREND ${ }_{B F A S T}$ ) as a function of environmental/climatic drivers $\left(\mathrm{R}_{(C V)}^{2}=0.50, \mathrm{RMSE}_{(R E L)}=35 \%, \mathrm{MAE}_{(R E L)}=26 \%\right.$ ). The relative importance analysis revealed that summer temperature was the most influential variable, followed by maximum snow water equivalent, and to a lesser extent, annual cumulative precipitation. The bivariate relationships between NDVI trend and the two most important climatic/environmental variables are shown in Figure 4. TREND ${ }_{B F A S T}$ is lower at colder locations and increases linearly with temperature, and it is more sensitive to temperature in the lower and upper temperature range, rather than in the median $\left(6-12{ }^{\circ} \mathrm{C}\right)$ range. TREND $B F A S T$ is also inversely correlated to SWE.

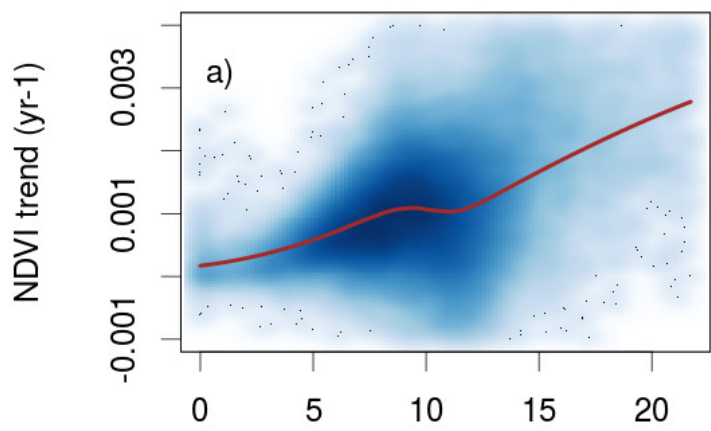

Summer temperature $\left({ }^{\circ} \mathrm{C}\right)$

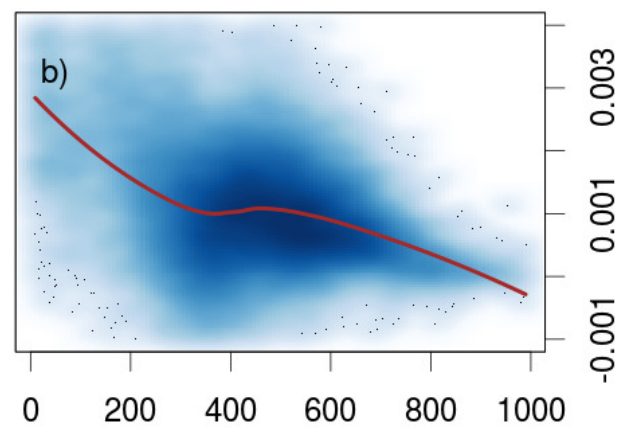

Maximum SWE $(\mathrm{mm})$

Figure 4. The relationship between NDVI trend (TREND $\left.{ }_{B F A S T}\right)$ and the two most important climatic variables. Blue color intensity is proportional to point density. Smoothed loess fit lines are reported in brown color. (a) Average summer temperature (2001-2018); (b) mean maximum snow water equivalent (SWE) (2002-2018).

Summer temperature and maximum SWE are strongly correlated to each other $(r=-0.9)$ and to elevation ( -0.97 and 0.92 for temperature and SWE, respectively), showing that the interplay of thermal and snow control on vegetation greenness co-varies with elevation, and the latter can be used as a proxy that integrates both snow and temperature. To consider the evolution of NDVI in the period 2000-2018 under markedly different thermal and snow regimes, we analyzed separately pixels above $1800 \mathrm{~m}$ and below $1500 \mathrm{~m}$. These elevation thresholds were chosen because on average all pixels below $1500 \mathrm{~m}$ are snow free on March 1st and we can assume no snow limitation on spring phenology. Pixels above $1800 \mathrm{~m}$ are snow-covered at list until May 1st, and we can hypothesize significant snow limitation on spring vegetation development above this elevation. 
On these two subsets, we compared monthly NDVI trajectories for the two periods 2000-2004 and 2014-2018 as representative of the beginning and end of the study period (Figure 5i,j). NDVI seasonal profile has evolved very differently in the two elevation bands from 2000 to 2018. Above 1800 $\mathrm{m}$, former and current NDVI seasonal patterns were very similar during the first part of the growing season, whereas current NDVI seasonal pattern is characterized by a higher maximum and a sustained greening throughout summer and early fall. Below $1500 \mathrm{~m}$, differences between former and current NDVI trajectories are already evident in spring, and the difference tends to reduce in late summer and fall. The general pattern described above is valid for all PFTs with some peculiarities (Figure 5a-h panels). Forested ecosystems above $1800 \mathrm{~m}$ show weaker greening in autumn compared to grasslands, shrublands, and screes. The difference between former and current areas under the curve (AUC) is positive at all elevations and for all PFTs but differs in magnitude, with twice as much of an increase above $1800 \mathrm{~m}$ compared to below $1500 \mathrm{~m}$. Scree slopes display the highest increase in AUC (40\%) during the study period, followed by shrublands, grasslands, and evergreen forests. AUC in deciduous forests increased by an equal rate of $8.4 \%$ at all elevations.

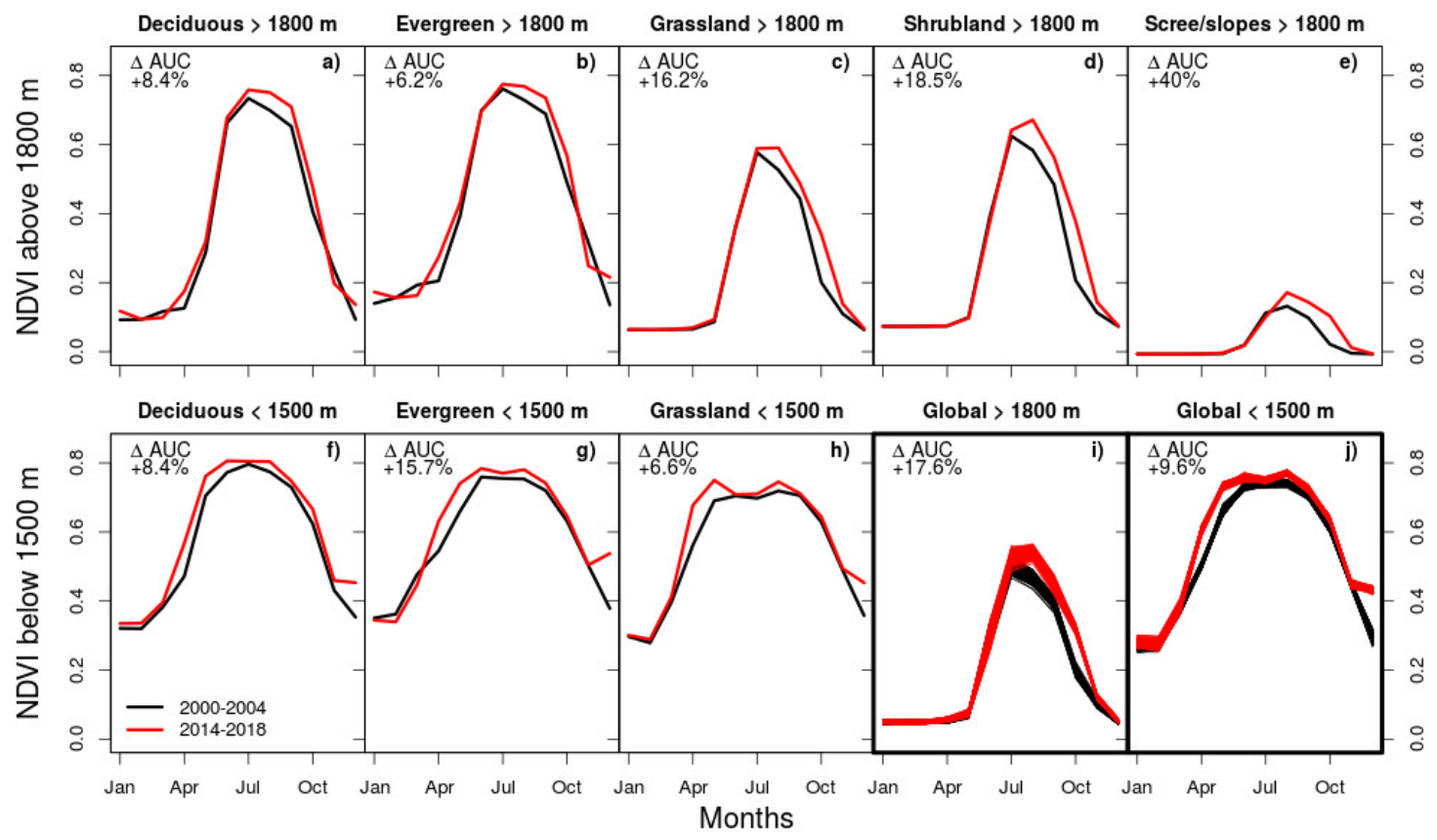

Figure 5. Spatio-temporal averages of monthly NDVI for the beginning (black lines) and end (red lines) of the study period. Monthly trajectories are averaged for all grid cells above $1800 \mathrm{~m}(\mathbf{a}-\mathbf{e})$ and below $1500 \mathrm{~m}(\mathbf{f}-\mathbf{h})$. Each panel features different plant functional types: deciduous forest (a,f), evergreen forest $(\mathbf{b}, \mathbf{g})$, grasslands $(\mathbf{c}, \mathbf{h})$, shrublands $(\mathbf{d})$, and scree slopes (e). Note that shrublands and screes below $1500 \mathrm{~m}$ cover less than 100 pixels and were not plotted. In (i,j) average NDVI trajectories across all PFTs are shown for grid cells above $1800 \mathrm{~m}(\mathbf{i})$ and below $1500 \mathrm{~m}(\mathbf{j})$. Because the number of grid cells in the two elevation bands was very different, we used a bootstrap approach sampling an even number of 1000 pixels for each elevation band 500 times. Curves resulting from the 500 replications are shown. In each panel, the increase in the area under the curve (AUC) between 2000-2004 and 2014-2018 is annotated.

\section{Discussion}

\subsection{Methodological Considerations}

We studied the rates, spatial patterns, and potential controls of greening in an inner-alpine region of the Western Alps by analyzing MODIS imagery for the period 2000-2018. The BFAST method allowed us to remove disturbed and non-linear signals from $\sim 37 \%$ of the vegetated land and 
to focus our analysis on widespread greening trends (Figure 2) representing more than half of the vegetated areas. Compared to the commonly used TREND $M A X$ method [18], TREND ${ }_{B F A S T}$ allows the exploitation of the whole time series [23] and thereby accounts for changes to seasonal NDVI profile that the TREND ${ }_{M A X}$ method neglects. We demonstrated that this method marks an improvement over the traditional TREND ${ }_{M A X}$; not only does it allow the detection of a greater number of pixels with significant trends (i.e., more statistical power) but it is also more robust against the saturation of NDVI signal (Figure 3). This issue, for example, prevented Carlson et al. [18] from investigating trends over forested areas with maximum NDVI higher than 0.75 in an Alpine region similar to the one analyzed in this study. Removing disturbed time series allowed us to exclude recent land-use change from this analysis; however, changes that occurred prior to year 2000 may still be affecting observed trends by means of legacy effects of past land-use practices or consistent land-use practices during recent years (i.e., extensive grazing). Finally, the moderate spatial resolution of MODIS data $(250 \mathrm{~m})$ limits our ability to interpret NDVI trends at small-scale, as, for example, at the level of alpine plant communities or in the case of changes in land-use or practices on limited surfaces.

\subsection{Controls and Mechanisms of Greening}

Snow and temperature regimes control the shape of greening in this region (Figure 5). The recent increase in air temperature recorded all over the Alps results generally in an earlier start of the growing season [20]. In our study, we confirmed this pattern below $1500 \mathrm{~m}$ (Figure $5 \mathrm{~b}$ ), where snow melts before March 1st and plant development can take advantage of warmer spring temperatures. Warmer springs therefore result in sustained greening in the transition from spring to summer, whereas the same is not true in the transition to fall, suggesting either photoperiod [42-44] or water limitation [45]. Between the two, we hypothesize water could be more likely the limiting factor, because (i) if photoperiod were the cause, a differential response between forests (more sensitive) and grasslands would be expected, but this was not the case (Figure 5), and/or (ii) lowlands in this inner alpine region receive rather low summer precipitation amounts $(<600 \mathrm{~mm} / \mathrm{yr})$, and water availability could be critical while approaching the end of the growing season. This is confirmed by the cumulated summer/fall water balance (precipitation-actual evapotranspiration) calculated for the two elevation belts, that averages $346 \pm 71$ and $179 \pm 62 \mathrm{~mm}$ above $1800 \mathrm{~m}$ and below $1500 \mathrm{~m}$, respectively (mean \pm 2 SE for the period 2008-2017). Even though an average value of $179 \mathrm{~mm}$ below $1500 \mathrm{~m}$ cannot be considered indicative of water stress, it may still represent sub-optimal conditions, compared to those observed above $1800 \mathrm{~m}$.

Above $1800 \mathrm{~m}$ the snow cover prevents the vegetation development until late spring. While a trend toward an earlier snow melt was reported at an alpine-wide scale by [20] for the 2000-2018 period, longer records suggest little evidence of earlier snow melt in the Alps after the 1990s [46]. For this reason, we hypothesize plants above $1800 \mathrm{~m}$ cannot take advantage of warmer springs due to the presence of snow cover [34]. It is likely, however, that this hypothesis applies only to the last 20 years, while before the 1990s, the combination of warmer temperatures and earlier snow melts determined an earlier beginning of the growing season even at high elevation, as documented by previous studies [47,48]. Instead, the majority of greening at high elevation is manifested toward summer and autumn, with remarkably higher NDVI values until October. Autumn plant senescence at high altitude occurs normally well before the snow onset, which indeed is not a limiting factor and the vegetation responds to warmer fall temperatures. An important role of photoperiod is suggested by the divergent behavior of trees versus grass-dominated ecosystems at high elevation (Figure 5a-d). The late-season greening trends strikingly differed between high elevation non-forested vegetation and forests. The pronounced trend for grasslands may reflect a predominant control by temperature. In contrast, the weaker response of forest to late-season warming may reflect a predominant control by photoperiod $[49,50]$.

Overall, the negative relationship between greening trend and maximum winter SWE (representing the quantity of water stored in the form of snow available in the watersheds at snow melt, Figure 4) seems counter-intuitive because we would expect that more water available may 
result in higher greening rates. However, we hypothesize that the observed inverse relationship reflects the control that snow cover exerts on spring phenology through the decoupling between air, canopy, and soil temperatures. Higher maximum SWE values are in fact associated with later snow melt, and both these conditions are more likely to occur at higher elevation, where trends are lower in magnitude. These results suggest that the water input from snow melt plays a marginal role in regulating the phenology of alpine ecosystems.

\subsection{Magnitude of Trends and Spatial Patterns}

Large differences in relative greening across plant types suggest that different mechanisms may be responsible for observed trends. NDVI in glacier forefields increased by up to $\sim 50 \%$ over the 2000-2018 period because of the colonization of previously glaciated areas [51,52]. To illustrate this feature, we selected MODIS pixels located in the proglacial area of the Rutor Glacier, one of the largest glacier bodies in Aosta Valley (Figure 6), based on historical ortophotographs. Areas deglaciated well before 1988 (at least 10 years) show a weakening NDVI trend, whereas the fastest greening rates are apparent at location where primary succession started $\sim 30$ years ago. Recently deglaciated areas (i.e., less than 20 years ago) are greening at an intermediate rate. This qualitative analysis shows that MODIS spatial resolution may be sufficient to inspect the phenomenon of primary succession in areas with flat and homogeneous proglacial morpohology. The process could be further analyzed using data from different satellites, like LANDSAT, providing longer time series at higher spatial resolution.

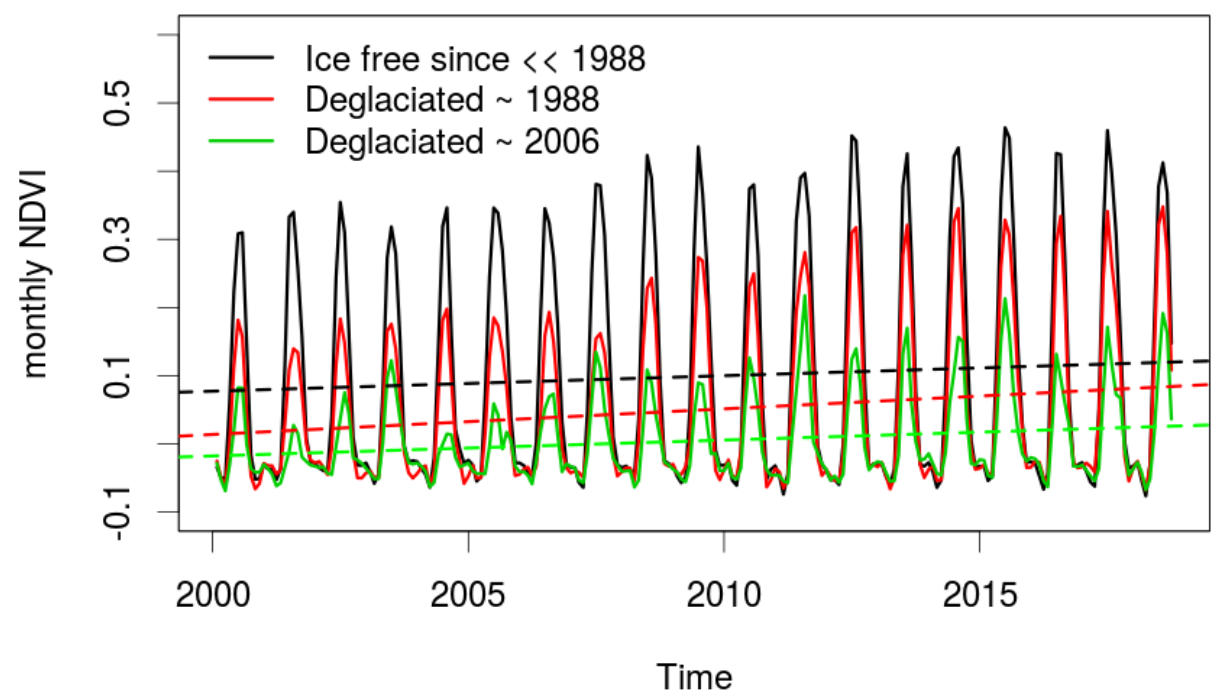

Figure 6. Time series of monthly NDVI in selected pixels located in the proglacial area of the Rutor Glacier $\left(45^{\circ} 40^{\prime} 12^{\prime \prime} \mathrm{N}, 6^{\circ} 59^{\prime} 11^{\prime \prime} \mathrm{E}, 2560 \mathrm{~m}\right.$ a.s.l.). Dashed lines indicate linear trends after time series decomposition.

In line with findings by [18], scree slopes at high elevation show a greening increase of more than $10 \%$ over the 2000-2018 period. This increase can be associated to plant colonization of previously non-vegetated surfaces consistent with the observed upward shift of herbaceous plant species [14,53]. Shrub and tree encroachment may be responsible for the $\sim 10 \%$ greening observed on shrublands, grasslands, and meadows. This process results largely from the abandonment of agricultural practices in previously managed areas [54] and can be in part attributed to rising temperatures, as well [55]. The magnitude of this process is further testified by the AUC increase of grasslands at high elevation, which is more than double than at low elevation, due to the fact that shrub encroachment caused by pasture and agricultural practices abandonment occurs more often at higher elevation than in the lowlands [56]. These phenomena are often localized and difficult to detect at $250 \mathrm{~m}$ spatial resolution. However, we illustrate the process in Figure 7. The visual comparison documents a sharp change in 
vegetation, reflected by a significant trend $(0.004 / \mathrm{yr}, 15 \% / 20 \mathrm{yr})$. Maximum summer NDVI in this area increased from 0.66 in 2000 to 0.85 in 2018.

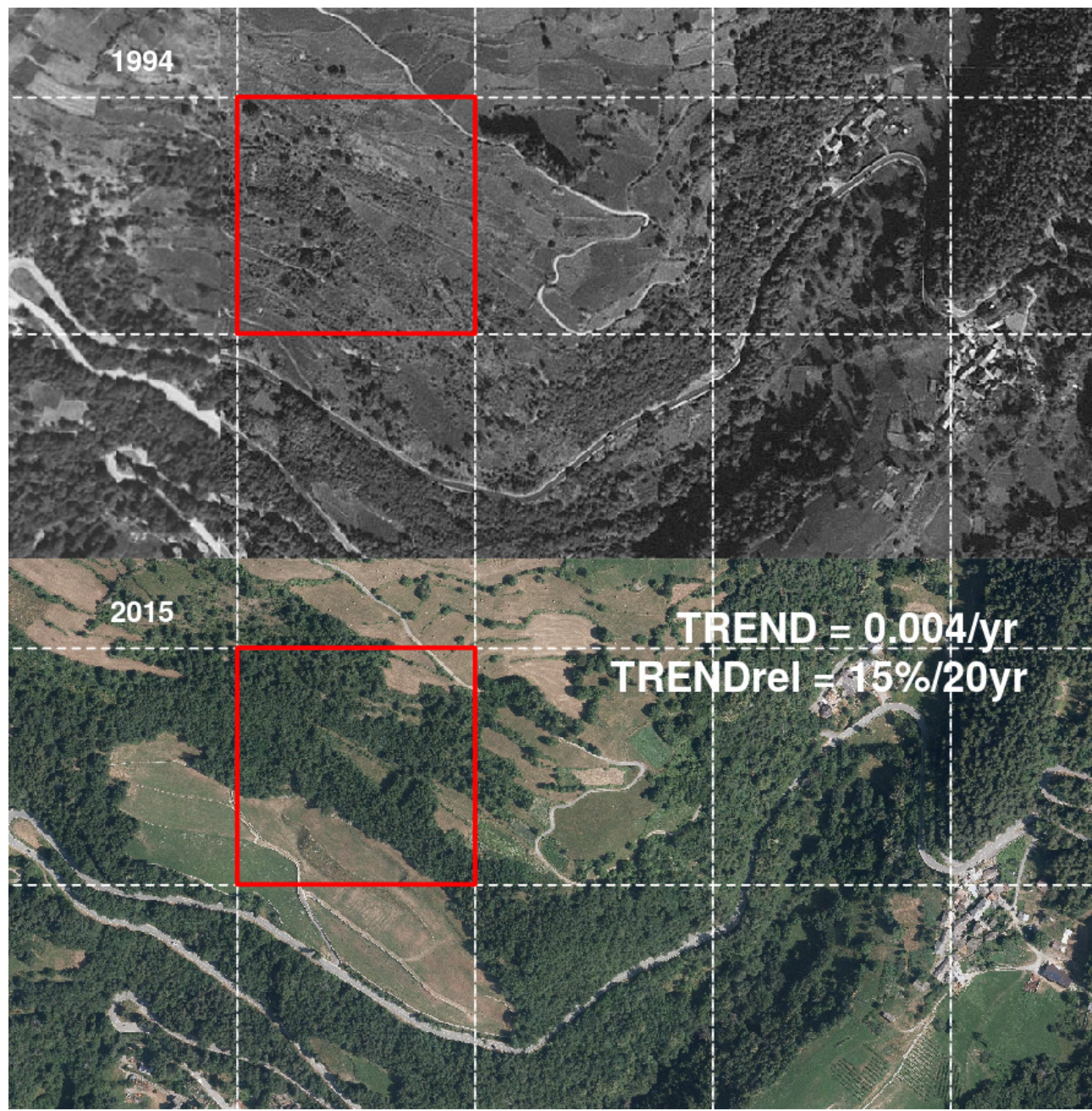

Figure 7. Shrub/tree encroachment illustrated by successive aerial photographs on a former meadow. TREND $_{B F A S T}$ is annotated. MODIS grid is drawn for reference. The pixel for which values are annotated is drawn in red.

\section{Conclusions}

This study provides evidence for widespread greening in the Alps and explores the climatic cues controlling its magnitude and spatial patterns. We found that warmer temperatures promote an increase in plant productivity, but that the seasonal timing of greening is regulated by other elevationand ecosystem-dependent factors. Among these, snow prevents spring plant development above $1800 \mathrm{~m}$ and photoperiod likely limits forested ecosystems in autumn, whereas at low elevation water and photoperiod both interact as limiting factors.

While more work is needed to disentangle the effects of the various climatic and environmental cues on greening trends, this study serves as a starting point for future research. For example, the dataset of disturbed pixels identified by the BFAST method, discarded here because beyond the scope of the paper, deserves a dedicated study addressing questions, such as the recovery speed after different types of disturbances, including fires, land-use changes, forest pest attacks, avalanches, landslides, etc. Additionally, as noted by [18], future studies on greening should expand the scale to an alpine-wide domain in order to: (i) confirm or discard patterns observed here and (ii) take into account processes operating at a larger scale, such as biogeographic gradients of precipitation, nitrogen deposition, and degree of disturbance. Finally, the combination of multiple sources of high-resolution 
satellite data can help addressing specific questions, such as impacts of drought and heat waves on greening trends or the dynamics of primary succession in the wake of glacier retreat.

Author Contributions: Conceptualization, G.F. and E.C.; methodology, G.F, E.C., M.G., M.I., and S.G.; software, G.F.; formal analysis, G.F.; investigation, G.F.; data curation, G.F;; writing-original draft preparation, G.F.; writing—review and editing, E.C., M.G., M.I., A.B., P.C., B.Z.C., S.G., U.M.d.C., M.M.; visualization, G.F.; supervision, U.M.d.C.; project administration, U.M.d.C.; funding acquisition, U.M.d.C., M.M.

Funding: This research was funded by the Project LIFE16 CCA/IT/000060 PASTORALP and EU ALCOTRA project AdaPT Mont-Blanc.

Acknowledgments: We thank two anonymous reviewers for their constructive comments.

Conflicts of Interest: The authors declare no conflict of interest.

\section{References}

1. Huang, K.; Xia, J.; Wang, Y.; Ahlstrom, A.; Chen, J.; Cook, R.B.; Cui, E.; Fang, Y.; Fisher, J.B.; Nicole Huntzinger, D.; et al. Enhanced peak growth of global vegetation and its key mechanisms. Nat. Ecol. Evol. 2018, 2. [CrossRef] [PubMed]

2. Zhu, Z.; Piao, S.; Myneni, R.B.; Huang, M.; Zeng, Z.; Canadell, J.G.; Ciais, P.; Sitch, S.; Friedlingstein, P.; Arneth, A.; et al. Greening of the Earth and its drivers. Nat. Clim. Chang. 2016, 6. [CrossRef]

3. Keenan, T.; Gray, J.; Friedl, M.A.; Toomey, M.; Bohrer, G.; Hollinger, D.; Munger, J.; O'Keefe, J.; Peter Schmid, H.; Sue Wing, I.; et al. Net carbon uptake has increased through warming-induced changes in temperate forest phenology. Nat. Clim. Chang. 2014, 4, 598-604. [CrossRef]

4. Beer, C.; Reichstein, M.; Tomelleri, E.; Ciais, P.; Jung, M.; Carvalhais, N.; Rodenbeck, C.; Arain, M.; Baldocchi, D.; Bonan, G.; et al. Terrestrial Gross Carbon Dioxide Uptake: Global Distribution and Covariation with Climate. Science 2010, 329, 834-838. [CrossRef] [PubMed]

5. Keenan, T.; Riley, W. Greening of the land surface in the World's cold regions consistent with recent warming. Nat. Clim. Chang. 2018, 8, 825. [CrossRef] [PubMed]

6. Barichivich, J.; Briffa, K.R.; Myneni, R.B.; Osborn, T.J.; Melvin, T.M.; Ciais, P.; Piao, S.; Tucker, C. Large-scale variations in the vegetation growing season and annual cycle of atmospheric $\mathrm{CO}_{2}$ at high northern latitudes from 1950 to 2011. Glob. Chang. Biol. 2013, 19, 3167-3183. [CrossRef]

7. Park, T.; Chen, C.; Macias-Fauria, M.; Tømmervik, H.; Choi, S.; Winkler, A.; Bhatt, U.S.; Walker, D.A.; Piao, S.; Brovkin, V.; et al. Changes in timing of seasonal peak photosynthetic activity in northern ecosystems. Glob. Chang. Biol. 2019, 25, 2382-2395. [CrossRef]

8. Macias-Fauria, M.; Forbes, B.; Zetterberg, P.; Kumpula, T. Eurasian Arctic greening reveals teleconnections andthe potential for structurally novel ecosystems. Nat. Clim. Chang. 2012, 2, 613-618. [CrossRef]

9. Croci-Maspoli, M.; Schär, C.; Fischer, A.; Strassmann, K.; Scherrer, S.; Schwierz, C.; Knutti, R.; Kotlarski, S.; Rajczak, J.; Fischer, E.; et al. CH2018-Climate Scenarios for Switzerland-Technical Report; National Centre for Climate Services: Zurich, Switzerland, 2018; 271p.

10. Gobiet, A.; Kotlarski, S.; Beniston, M.; Heinrich, G.; Rajczak, J.; Stoffel, M. 21st century climate change in the European Alps-A review. Sci. Total Environ. 2014, 493, 1138-1151. [CrossRef]

11. Durand, Y.; Giraud, G.; Laternser, M.; Etchevers, P.; Mérindol, L.; Lesaffre, B. Reanalysis of 47 Years of Climate in the French Alps (1958-2005): Climatology and Trends for Snow Cover. J. Appl. Meteorol. Climatol. 2009, 48, 2487-2512. [CrossRef]

12. Hüsler, F.; Jonas, T.; Riffler, M.; Musial, J.P.; Wunderle, S. A satellite-based snow cover climatology (1985-2011) for the European Alps derived from AVHRR data. Cryosphere 2014, 8, 73-90. [CrossRef]

13. Cazzolla Gatti, R.; Dudko, A.; Lim, A.; Velichevskaya, A.I.; Lushchaeva, I.V.; Pivovarova, A.V.; Ventura, S.; Lumini, E.; Berruti, A.; Volkov, I.V. The last 50 years of climate-induced melting of the Maliy Aktru glacier (Altai Mountains, Russia) revealed in a primary ecological succession. Ecol. Evol. 2018, 8, 7401-7420. [CrossRef] [PubMed]

14. Rogora, M.; Frate, L.; Carranza, M.; Freppaz, M.; Stanisci, A.; Bertani, I.; Bottarin, R.; Brambilla, A.; Canullo, R.; Carbognani, M.; et al. Assessment of climate change effects on mountain ecosystems through a cross-site analysis in the Alps and Apennines. Sci. Total Environ. 2018, 624. [CrossRef] [PubMed] 
15. Harsch, M.A.; Hulme, P.E.; McGlone, M.S.; Duncan, R.P. Are treelines advancing? A global meta-analysis of treeline response to climate warming. Ecol. Lett. 2009, 12, 1040-1049. [CrossRef]

16. Bolton, D.K.; Coops, N.C.; Hermosilla, T.; Wulder, M.A.; White, J.C. Evidence of vegetation greening at alpine treeline ecotones: Three decades of Landsat spectral trends informed by lidar-derived vertical structure. Environ. Res. Lett. 2018, 13, 084022. [CrossRef]

17. Steinbauer, M.; Grytnes, J.A.; Jurasinski, G.; Kulonen, A.; Lenoir, J.; Pauli, H.; Rixen, C.; Winkler, M.; Bardy-Durchhalter, M.; Barni, E.; et al. Accelerated increase in plant species richness on mountain summits is linked to warming. Nature 2018, 556. [CrossRef]

18. Carlson, B.Z.; Corona, M.C.; Dentant, C.; Bonet, R.; Thuiller, W.; Choler, P. Observed long-term greening of alpine vegetation-A case study in the French Alps. Environ. Res. Lett. 2017, 12, 114006. [CrossRef]

19. Corona-Lozada, M.; Morin, S.; Choler, P. Drought offsets the positive effect of summer heat waves on the canopy greenness of mountain grasslands. Agric. For. Meteorol. 2019, 276, 107617. [CrossRef]

20. Asam, S.; Callegari, M.; Matiu, M.; Fiore, G.; Gregorio, L.; Jacob, A.; Menzel, A.; Zebisch, M.; Notarnicola, C. Relationship between Spatiotemporal Variations of Climate, Snow Cover and Plant Phenology over the Alps-An Earth Observation-Based Analysis. Remote Sens. 2018, 10, 1757. [CrossRef]

21. de Jong, R.; Verbesselt, J.; Schaepman, M.E.; de Bruin, S. Trend changes in global greening and browning: Contribution of short-term trends to longer-term change. Glob. Chang. Biol. 2012, 18, 642-655. [CrossRef]

22. Emmett, K.D.; Renwick, K.M.; Poulter, B. Disentangling Climate and Disturbance Effects on Regional Vegetation Greening Trends. Ecosystems 2019, 22, 873-891. [CrossRef]

23. Verbesselt, J.; Hyndman, R.; Newnham, G.; Culvenor, D. Detecting Trend and Seasonal Changes in Satellite Image Time Series. Remote Sens. Environ. 2010, 114, 106-115. [CrossRef]

24. Verbesselt, J.; Hyndman, R.; Zeileis, A.; Culvenor, D. Phenological Change Detection while Accounting for Abrupt and Gradual Trends in Satellite Image Time Series. Remote Sens. Environ. 2010, 114, 2970-2980. [CrossRef]

25. Geng, L.; Che, T.; Wang, X.; Wang, H. Detecting Spatiotemporal Changes in Vegetation with the BFAST Model in the Qilian Mountain Region during 2000-2017. Remote Sens. 2019, 11, 103. [CrossRef]

26. Silvestro, F.; Gabellani, S.; Rudari, R.; Delogu, F.; Laiolo, P.; Boni, G. Uncertainty reduction and parameter estimation of a distributed hydrological model with ground and remote-sensing data. Hydrol. Earth Syst. Sci. 2015, 19, 1727-1751. [CrossRef]

27. Silvestro, F.; Gabellani, S.; Delogu, F.; Rudari, R.; Boni, G. Exploiting remote sensing land surface temperature in distributed hydrological modelling: The example of the Continuum model. Hydrol. Earth Syst. Sci. 2013, 17, 39-62. [CrossRef]

28. Deardorff, J.W. Dependence of air-sea transfer coefficients on bulk stability. J. Geophys. Res. (1896-1977) 1968, 73, 2549-2557. [CrossRef]

29. Evans, D. The Habitats of the European Union Habitats Directive. Biol. Environ. Proc. R. Irish Acad. 2006, 106, 167-173. [CrossRef]

30. Comission DG Environment, E. The Interpretation Manual of European Union Habitats-EUR27. Eur. Comm. DG Environ. Nat. Biodivers. 2007, 27, 368.

31. Vermote, E. MOD09Q1 MODIS/Terra Surface Reflectance 8-Day L3 Global 250m SIN Grid V006. NASA EOSDIS Land Processes DAAC. 2015. Available online: https://doi.org/10.5067/MODIS/MOD09Q1.006 (accessed on 5 January 2019).

32. Busetto, L.; Ranghetti, L. MODIStsp: An R package for preprocessing of MODIS Land Products time series. Comput. Geosci. 2016, 97, 40-48. [CrossRef]

33. Busetto, L.; Colombo, R.; Migliavacca, M.; Cremonese, E.; Meroni, M.; Galvagno, M.; Rossini, M.; Siniscalco, C.; Morra Di Cella, U.; Pari, E. Remote sensing of larch phenological cycle and analysis of relationships with climate in the Alpine region. Glob. Chang. Biol. 2010. [CrossRef]

34. Choler, P. Growth response of temperate mountain grasslands to inter-annual variations in snow cover duration. Biogeosciences 2015, 12, 3885-3897. [CrossRef]

35. Sen, K.P. Estimates of the Regression Coefficient Based on Kendall's Tau. J. Am. Stat. Assoc. 1968, 63. [CrossRef]

36. Cleveland, B.R.; Cleveland, S.W.; McRae, E.J.; Terpenning, I. STL: A Seasonal-Trend Decomposition Procedure Based on Loess. J. Off. Stat. 1990, 6, 3-33. 
37. Wright, M.N.; Ziegler, A. ranger: A Fast Implementation of Random Forests for High Dimensional Data in C++ and R. J. Stat. Softw. 2017, 77, 1-17. [CrossRef]

38. Kuhn, M. Caret: Classification and Regression Training; R Package Version 6.0-79. 2018. Available online: http:/ / adsabs.harvard.edu/abs/2015ascl.soft05003K (accessed on 1 October 2019).

39. R Core Team. R: A Language and Environment for Statistical Computing; R Foundation for Statistical Computing: Vienna, Austria, 2019.

40. Geurts, P.; Ernst, D.; Wehenkel, L. Extremely Randomized Trees. Mach. Learn. 2006, 63, 3-42. [CrossRef]

41. McCune, B.; Keon, D. Equations for potential annual direct incident radiation and heat load. J. Veg. Sci. 2002, 13, 603-606. [CrossRef]

42. Richardson, A.D.; Keenan, T.F.; Migliavacca, M.; Ryu, Y.; Sonnentag, O.; Toomey, M. Climate change, phenology, and phenological control of vegetation feedbacks to the climate system. Agric. For. Meteorol. 2013, 169, 156-173. [CrossRef]

43. Migliavacca, M.; Cremonese, E.; Colombo, R.; Busetto, L.; Galvagno, M.; Ganis, L.; Meroni, M.; Pari, E.; Rossini, M.; Siniscalco, C.; et al. European larch phenology in the Alps: Can we grasp the role of ecological factors by combining field observations and inverse modelling? Int. J. Biometeorol. 2008, 52, 587-605. [CrossRef]

44. Migliavacca, M.; Galvagno, M.; Cremonese, E.; Rossini, M.; Meroni, M.; Sonnentag, O.; Cogliati, S.; Manca, G.; Diotri, F.; Busetto, L.; et al. Using digital repeat photography and eddy covariance data to model grassland phenology and photosynthetic $\mathrm{CO}_{2}$ uptake. Agric. For. Meteorol. 2011, 151, 1325-1337. [CrossRef]

45. Buermann, W.; Forkel, M.; O’Sullivan, M.; Sitch, S.; Friedlingstein, P.; Haverd, V.; Jain, A.K.; Kato, E.; Kautz, M.; Lienert, S.; et al. Widespread seasonal compensation effects of spring warming on northern plant productivity. Nature 2018, 562. [CrossRef] [PubMed]

46. Klein, G.; Vitasse, Y.; Rixen, C.; Marty, C.; Rebetez, M. Shorter snow cover duration since 1970 in the Swiss Alps due to earlier snowmelt more than to later snow onset. Clim. Chang. 2016. [CrossRef]

47. Menzel, A.; Sparks, T.; Estrella, N.; Koch, E.; Aasa, A.; Ahas, R.; Alm-Kubler, K.; Bissolli, P.; Braslaskva, O.; Briede, A.; et al. European phenological response to climate change matches the warming pattern. Glob. Chang. Biol. 2006, 12, 1969-1976. [CrossRef]

48. Parmesan, C.; Yohe, G. A globally coherent fingerprint of climate change impacts across natural systems. Nature 2003, 421, 37-42. [CrossRef] [PubMed]

49. Way, D.A.; Montgomery, R.A. Photoperiod constraints on tree phenology, performance and migration in a warming world. Plant Cell Environ. 2015, 38, 1725-1736. [CrossRef]

50. Ren, S.; Yi, S.; Peichl, M.; Wang, X. Diverse Responses of Vegetation Phenology to Climate Change in Different Grasslands in Inner Mongolia during 2000-2016. Remote Sens. 2018, 10, 17. [CrossRef]

51. Eichel, J.; Krautblatter, M.; Schmidtlein, S.; Dikau, R. Biogeomorphic interactions in the Turtmann glacier forefield, Switzerland. Geomorphology 2013, 201, 98-110. [CrossRef]

52. D'Amico, M.E.; Freppaz, M.; Filippa, G.; Zanini, E. Vegetation influence on soil formation rate in a proglacial chronosequence (Lys Glacier, NW Italian Alps). CATENA 2014, 113, 122-137. [CrossRef]

53. Grabherr, G.; Gottfried, M.; Pauli, H. Climate Change Impacts in Alpine Environments. Geogr. Compass 2010, 4, 1133-1153. [CrossRef]

54. Améztegui, A.; Brotons, L.; Coll, L. Land-use changes as major drivers of mountain pine (Pinus uncinata Ram.) expansion in the Pyrenees. Glob. Ecol. Biogeogr. 2010, 19, 632-641. [CrossRef]

55. Elmendorf, S.C.; Henry, G.; Hollister, R.; Björk, R.; Boulanger-Lapointe, N.; Cooper, E.J.; Cornelissen, J.; Day, T.; Dorrepaal, E.; Elumeeva, T.; et al. Plot-scale evidence of tundra vegetation change and links to recent summer warming. Nat. Clim. Chang. 2012, 2. [CrossRef]

56. Koch, B.; Edwards, P.J.; Blanckenhorn, W.U.; Walter, T.; Hofer, G. Shrub Encroachment Affects the Diversity of Plants, Butterflies, and Grasshoppers on Two Swiss Subalpine Pastures. Arctic Antarct. Alp. Res. 2015, 47, 345-357. [CrossRef]

(C) 2019 by the authors. Licensee MDPI, Basel, Switzerland. This article is an open access article distributed under the terms and conditions of the Creative Commons Attribution (CC BY) license (http:/ / creativecommons.org/licenses/by/4.0/). 